\title{
ФОРМИРОВАНИЕ И ПОХОДНЫЙ МАРШ 1-ГО ПОЛКА НИЖЕГОРОДСКОГО ОПОЛЧЕНИЯ 1812 Г. (СЕНТЯБРЬ 1812 - МАРТ 1813 ГГ.)
}

\section{FORMATION AND MARCHING OF THE 1-D REGIMENT OF THE NIZHNY NOVGOROD MILITIA IN 1812 (SEPTEMBER 1812-MARCH 1813)}

D. Nikolaev

I. Khvostova

Summary: In this article, on the basis of archival materials of the Central archive of Nizhny Novgorod region (TSANO) discusses issues about the peculiarities of formation of one of the divisions of the Nizhny Novgorod militia in the era of 1812 - 1-d regiment, and, on the basis of the regimental reports, provides information about Hiking the March, coupled with data about numbers, logistics and other information that characterize the «private» episode of fighting for the nomination militia units of the Russian army to the borders of the Russian Empire to further commission of a foreign campaign.

Keywords: Patriotic War of 1812, Nizhny Novgorod militia in 1812 , marching march, weapon, equipment.

\section{Николаев Дмитрий Андреевич}

К.и.н., доцент, Нижегородский государственный университет им. Н.И. Лобачевского

dmnikolaeff@mail.ru

Хвостова Ирина Алексеевна

К.и.н., дочент, Нижегородский государственный университет им. Н.И. Лобачевского

iri-khv@mail.ru

Аннотация: В данной статье на основе архивных материалов Центрального архива Нижегородской области (ЦАНО) рассматриваются вопросы об особенностях формирования одного из подразделений нижегородского ополчения в эпоху 1812 г. - 1-го полка, а также, на основе полковых рапортов, приводятся сведения 0 его походном марше, вкупе с данными об изменении численного состава, снабжении и прочими сведениями, характеризующими «частный» эпизод боевого выдвижения ополченского подразделения русской армии к границам Российской Империи для дальнейшего совершения заграничного похода.

Ключевые слова: Отечественная война 1812 г., нижегородское ополчение 1812 г., походный марш, оружие, снаряжение.

ный статский советник П.Ф. Козлов [18, с.115]. Среди полномочных структур, созданных специально для этой цели, особо выделялись, по своему значению и функциям, комитеты пожертвований [5, с.95] и вооружения [12, с.58]. Обмундирование [13, с.58], снаряжение и даже вооружение [9, с.75] ополчений той поры осуществлялось за счет «отдатчиков ратников», т.е. помещиков [10, с.345], либо мещанских сообществ [15, с.35]. Все полки нижегородского ополчения входили в состав так называемого III ополченского округа (вместе с ополчениями казанским, вятским, симбирским, пензенским и костромским) под предводительством генерал-лейтенанта П.А. Толстого [7, с.67]; начальником же нижегородского ополчения являлся князь Г.А. Грузинский.

1-й пехотный полк нижегородского ополчения формировался в Нижнем Новгороде из ратников, призванных, в основном, из Нижнего Новгорода, Балахны и Макарьева. По рапорту командира полка Каратаева, состав полка к 25-му октября 1812 г. выглядел следующим образом:

«По списку состоит»: полковых начальников-1. батальонных начальников-4; сотенных-16; пятидесятных-23; урядников-90; писарей-2; барабанщиков-нет; воинов2313 


\section{«Больных офицеров»-нет}

«Больных воинов»: в лазарете-10; в околотке-5

«В недостатке»: воинов-87; писарей-24; урядников-86, пятидесятных-9, барабанщиков-37 «Налицо состоит»: полковых начальников-1. батальонных начальников-4; сотенных-16; пятидесятных-23; урядников-90; писарей-2; барабанщиков-нет; воинов- 2313

«Арестованных»-нет

«В отпуску»-нет [20, л.5]

Следует также отметить, что к 25-му октября 7 воинов бежали из полка (Г.И. Анчугов, В. Орехов, Я. Житков, П. Харламов, И. Макаров, Т. Кулагин, И. Иванов) [20, л.2], а 12 человек находились в Нижегородской градской больнице [20, л.3]. К 30-му октября 1812 г. основной состав полка был набран и ратников, «состоявших налицо», насчитывалось 2404 человек [21, л.2]. Из числа набранных воинов (которые продолжали поступать), 118 человек были направлены под начало генерал-майора Ильина в «артиллерийскую лабораторию для делания боевых патронов» на «бессменно долгое время» $(95$, л.3) и это нашло свое отражение в очередном командирском рапорте от 10 ноября 1812 г.:

«По списку состоит»: полковых начальников-1. батальонных начальников-4; сотенных-16; пятидесятных-21; урядников-87; писарей-4; барабанщиков-нет; воинов2320

«Больных офицеров»-батальонный начальник Дмитриев

«Больных воинов»: в лазарете-32; в околотке-27

«В командировке воинов»: 118 («для делания патронов»)

«В недостатке»: воинов-80; писарей-22; урядников-89, пятидесятных-11, барабанщиков-37 «Налицо состоит»: полковых начальников-1. батальонных начальников-3; сотенных-12; пятидесятных-21; урядников-89; писарей-4; барабанщиков-нет; воинов- 2148

«Арестованных»-нет

«В отпуску»-нет [20, л.7]

Военная учеба некоторых подразделений формируемого полка проходила в Нижнем Новгороде недалеко от Печерского монастыря, где случилось чрезвычайное происшествие, вызванное оттепелью, а именно: сход снежной лавины, которая накрыла часть ратников 2-го батальона 1-го полка. Это происшествие оставило свой след в нарративе по отечественной истории, поскольку о нем упоминается в известных воспоминаниях Э.Г. Эрстрема, который написал, со слов других, что «ополченцам...тут же выдали лопаты и шесты, чтобы откопать несчастных своих товарищей. Нашли всех, но ни один не избежал поранений и увечий от собственных пик и ружей. Один ополченец погиб» [22, с.154]. Но на самом деле серьезных последствий этого инцидента удалось избежать как благодаря быстрой и слаженной работе, очевидно, большого количества людей - как ополчен- цев, так и местных жителей - по вызволению людей из снежного плена, так и благодаря умелому командованию со стороны полковника Каратаева, очевидца и непосредственного участника события. Вопреки повествованию Эрстрема, в донесении Каратаева о случившемся не упоминается о погибших, а только о двух раненых: воины «оказались, по осмотру моему, от сего несчастного случая совершенно неповрежденными, только из числа сих двое, из коих одному помяло ногу, а второму живот, кои и находятся теперь в лазарете...» [21, л.6]. В декабре 1812 г. полковник Каратаев был назначен командиром бригады (состоящей из 1-го и 2-го полков); еще ранее он назначил себе адъютантом сотенного Денисова [21, л.5]. На 1-е декабря 1812 г. состав полка был следующим:

«По списку состоит»: полковых начальников-1. батальонных начальников-4; сотенных-16; пятидесятных-23; урядников-108; писарей-4; барабанщиков-нет; воинов2314

«Больных офицеров»-батальонный начальник Дмитриев

«Больных воинов»: в лазарете-53; в околотке-1

«В командировке воинов»: 118

«В недостатке»: воинов-86; писарей-22; урядников-68, пятидесятных-9, барабанщиков-37

«Налицо состоит»: полковых начальников-1; батальонных начальников-3; сотенных13; пятидесятных-26; урядников-104; писарей-3; барабанщиков-нет; воинов2082

«Арестованных»-нет

«В отпуску»-нет $[20, л .8]$

Согласно рапорта от 15 декабря, полк пополнился «комплектом» барабанщиков (из обученных «барабанной науке» солдат полка), но заметно уменьшился в реальной численности из-за возрастающего количества заболевающих: «По списку состоит»: полковых начальников-1. батальонных начальников-4; сотенных-16; пятидесятных-28; урядников-132; нестроевых-130; барабанщиков-40; воинов- 2021

«Больных офицеров»-пятидесятный Топоров

«Больных воинов»: в лазарете-49; в околотке-42

«В командировке воинов»-105

«В недостатке»: воинов-19

«Налицо состоит»: полковых начальников-1, батальонных начальников-3; сотенных13; пятидесятных-26; урядников-128; нестроевых-130; барабанщиков-40; воинов-1826

«Арестованных»-нет

«В отпуску»-нет [20, л.9]

При отправлении полка в поход в Нижнем Новгороде был оставлен заболевший пятидесятник Водов [21, л.7], а в дальнейшем болезни личного состава полка только усугубились не только из-за суровых климатических и походных условий, но и из-за отсутствия своевременной и квалифицированной медицинской помощи, о чем 
свидетельствует донесение Каратаева Грузинскому от начала января 1813 г.: «при следовании вверенной мне бригады 1-го и 2-го полков в повеленный поход трудно больные воины без медицинского чиновника в болезнях своих не имеют никакой помощи и изнуряются от пути беспокойством более получая себе слабости, а хотя по правилам о марше предписано таковых больных довозить до Тулы, где оставлять в лазарете для ополчения приготовленном, но я, обозревая на марше означенные полки, будучи сам свидетелем такого жалостного положения больных воинов из сострадания... решился такого состояния воинов оставлять в предлежащих к Туле в городах больницах, или гошпиталях на тех же правилах, как от начальства предписано оставлять их в тульском лазарете...» [21, л.9]. Согласно предписаниям, действительно требовалось довозить больных воинов до губернских центров, где была наиболее подготовленная для этого инфраструктура и медицинский персонал. Но в конкретных условиях похода многочисленных ополченских и армейских подразделений это правило, фактически, перестало выполняться и больных оставляли практически в любых медико-санитарных учреждениях и даже у частных лиц.

Полк прошел Нижегородскую и Владимирскую губернии «безобидно и благополучно» [21, л.17]; во время следования полка по Рязанской губернии «чрез город Касимов оказались воины столь трудно больные, что никак не могли следовать в поход за полками без подвержения жизни их опасности, почему и оставлены в касимовском военном госпитале...М.И. Седов, И.М. Воробьев, С.Д. Охлопков, М. Иванов, В. Алексеев...» [21, л.16]. По рапорту Каратаева от 4-го февраля 1813 г. в полку значилось:

«По списку состоит»: полковых начальников-1. батальонных начальников-4; сотенных-12; пятидесятных-32; урядников-114; нестроевых-130; барабанщиков-40; воинов- 1937

«Больных офицеров»: сотенный Степанов («умер в Муроме»), сотенный Петров, пятидесятные Водов и Андреев

«Больных воинов»: в лазарете - 88; в околотке -159
«В командировке воинов»: 1

«В недостатке»: воинов-103, урядников-18, пятидесятных-1, сотенных-1

«Налицо состоит»: полковых начальников-1, батальонных начальников-3; сотенных - 9; пятидесятных-25; урядников-110; нестроевых-99; барабанщиков-40; воинов-1710

«Арестованных»-нет

«В отпуску»-нет [20, л.16]

В феврале 1813 г., во время продолжающегося похода, в полку заметили, что стало приходить в негодность огнестрельное оружие [21, л.19]. Для решения возникших проблем Каратаев, первоначально, планировал отправить партию неисправного оружия, в сопровождении офицера, в Тулу (один из важнейших центров производства вооружения) и «привесть в исправность за умеренную цену из суммы, отпущенной на непредвиденные надобности» [21, л.19], но затем изменил свои планы, и, поскольку полк отдалился от Тулы уже более чем на 200 верст, решил искать оружейные и слесарные производства далее по пути [21, л.19]. Также известно, что в феврале 1813 г. Каратаев получил 2000 руб. на покупку провианта и фуража [19, л.3], а также 1610 руб. 40 коп. «воинам на винную и мясную порции» $[19$, л.3]. «Курской губернии Фатежского земского суда дворянский заседатель Шалимов» $[21$, л.20] привез Каратаеву предписание от курского губернатора А.И. Нелидова, согласованное с военным командованием, об изменении маршрута следования полка.

По прибытии полка в Глухов, Каратаев, не имея дальнейших маршрутных предписаний, «решился следовать прямейшим до Киева трактом». Из его сообщений видно, что Черниговская губерния, через которую продвигался полк, стала одним из центров масштабного военного транзита, «беспрестанного перехода многих и разных войск», а потому имели место перебои со снабжением и подвозом всего необходимого. В марте 1813 г. полк достиг намеченных по плану населенных пунктов в Киевской и Волынской губерниях, где стал готовиться к дальнейшему заграничному походу.

\section{ЛИТЕРАТУРА}

1. Грубов В.И., Николаев Д.А. Вопросы архивоведения и источниковедения в высшей школе//Отечественные архивы. 2018. №1. С.116-117

2. Грубов В.И., Николаев Д.А. Вопросы архивоведения и источниковедения в высшей школе//Отечественные архивы. 2019. №2. С.129-131

3. Дорофеев Ф.А., Николаев Д.А. Особенности формирования офицерского корпуса в нижегородском ополчении 1812 г.//Вопросы истории. 2020 . №1. C.121-128

4. Дроздов Ф.Б., Николаев Д.А. Народное ополчение 1812 г. и общественный договор//Вестник Нижегородского университета им. Н.И.Лобачевского. 2012. №6 (3). C.95-99

5. Егоров Г.В., Николаев Д.А. Формирование «подвижного магазейна» по снабжению армии в Нижегородской губернии в 1812 г.//Гуманитарные и социально-экономические науки. 2017. №5 (96). С.95-98

6. Кауркин Р.В., Дроздов Ф.Б., Николаев Д.А. Отечественная война 1812 г. Нижегородское ополчение и его участие в заграничных походах 1813-1814 гг. Н. Новгород: НО ИРИ, 2012. 158 с. 
7. Николаев Д.А. Добровольцы в нижегородском ополчении 1812 г.: исторические реалии и историографические мифы//Вестник Нижегородского университета им. Н.И.Лобачевского.2018. №2. С.67-77

8. Николаев Д.А. Заболеваемость офицеров нижегородского ополчения 1812 г. (по материалам официального делопроизводства начала XIX века)// Оборонно-промышленный комплекс России: исторический опыт и современные стратегии. Сборник материалов II Всероссийской научно-практической конференции. 2017. С.96-99

9. Николаев Д.А. Как и чем вооружалось нижегородское ополчение в 1812 году//Военно-исторический журнал. 2019. №2. С.75-79

10. Николаев Д.А. Комплекс документов по вопросам продовольственного и вещевого обеспечения нижегородского ополчения 1812 г.//Торговля, купечество и таможенное дело в России в XVI - XIX вв. Сборник материалов Четвертой международной научной конференции. Редактор-составитель А.И. Раздорский. Редколлегия: В.Н. Беляева [и др.]. 2018. С.345-349

11. Николаев Д.А. Материалы официального делопроизводства по вопросам продовольственного и вещевого обеспечения нижегородского ополчения 1812 г.//Вопросы архивоведения и источниковедения в высшей школе. Сборник статей участников XVI Региональной научно-практической конференции. Под редакцией В.И. Грубова, А.А. Исакова. 2019. С.39-43

12. Николаев Д.А. Некоторые аспекты развития военного производства Нижегородской губернии в начале XIX века (на примере вооружения нижегородского ополчения 1812 г.)//0боронно-промышленный комплекс России: исторический опыт и современные стратегии. Сборник материалов II Всероссийской научно-практической конференции. 2017. С.58-62

13. Хвостова И.А., Николаев Д.А. Инспекторский смотр обмундирования и снаряжения нижегородского ополчения в 1812 г.//Современная наука: актуальные проблемы теории и практики. Серия «Гуманитарные науки». 2017. №12. С.58-61

14. Хвостова И.А., Николаев Д.А. Логистические особенности обеспечения нижегородского ополчения 1812 г. на начальном этапе его формирования (сентябрь - октябрь 1812 г.)//Вопросы истории. 2020. №2. С.217-224

15. Хвостова И.А., Николаев Д.А. Страницы истории нижегородского ополчения 1812 г.: проблема «лишнего» оружия//Современная наука: актуальные проблемы теории и практики. Серия «Гуманитарные науки». 2019. №9. С.35-37

16. Хвостова И.А., Николаев Д.А. «...Упражняются. . . в пьянстве и буйстве. . .»: формирование и девиантные особенности походного марша 3-го полка нижегородского ополчения (сентябрь 1812 - июнь 1813 гг.)//История: факты и символы. 2019. №4 (21). С.27-36

17. Хвостова И.А., Николаев Д.А. Формирование и походный марш 5-го полка нижегородского ополчения 1812 г. (сентябрь 1812 - апрель 1813 гг.)//Гуманитарные и социально-экономические науки. 2019. №3 (106). С.98-103

18. Хвостова И.А., Николаев Д.А. Формирование и походный марш конного полка нижегородского ополчения 1812 г. (сентябрь 1812 - февраль 1813 гг.)// Гуманитарные и социально-экономические науки. 2018. №2 (99). С.115-119

19. Центральный архив Нижегородской области (ЦАНО), Ф.1822, 0п.1, Д.12

20. ЦАНО, Ф.1822, Оп.1, Д.92

21. ЦАНО, Ф.1822, Оп.1, Д.95

22. Эрстрём Э.Г. 1812 год. Путешествие из Москвы в Нижний Новгород / сост. и вступ. ст. Г.М. Коваленко, А.А. Кузнецов; коммент. С.Н. Искюль, Г.М. Коваленко, АА. Кузнецова, А.В. Морохина. Н. Новгород: Изд-во ННГУ им. Н.И. Лобачевского. 2013. 